\title{
Gondolatok a fejlesztési segélyek negatív hatásairól P. T. Bauer szellemi örökségének tükrében
}

\begin{abstract}
Jelen tanulmány a magyar származású Peter Thomas Bauer szellemi örökségéröl kíván áttekintést nyújtani - ő akkor hirdetett a fejlesztéspolitika területén szabadpiaci elveket, amikor az uralkodó megközelítés a központi tervezés és a fejlesztési segélyezés volt. Munkássága először heterodoxnak tünt, majd a hetvenes évek végétől hirtelen a fóáram része lett. Megítélését mindez még ma is polemikussá teszi, ráadásul nem segíti a róla kialakított kép megértését az sem, hogy elméletei csak rendkívül felületesen vagy egyáltalán nem ismertek. Bauer szellemi örökségének áttekintése ugyanakkor rámutat arra, hogy számos kérdésben igaza volt: többek között azonnal meglátta a központilag irányított fejlesztéspolitika káros hatásait. Munkásságának ismerete fontos, mert Bauer volt a fejlesztési segélyezés legélesebb magyar származású kritikusa - illik rá emlékeznünk.
\end{abstract}

Journal of Economic Literature (JEL) kód: B31, F35, O10.

Jelen tanulmány annak a Peter Thomas Bauernek a szellemi örökségét igyekszik feltárni, aki a második világháború után évtizedeken keresztül szembehelyezkedett azokkal az - általa fejlesztési szakértőknek titulált - közgazdászokkal, akik a fejlődés zálogát az átfogó központi tervezésben, a protekcionizmusban és a fejlesztési segélyekben látták. Sokak szemében ő testesítette meg a „fejlődés eretnekét” a többi eretnek között. Munkássága során elsődlegesen heterodox besorolást kapott, később azonban, a hetvenes évek végi politikai és gazdasági változásokat követően ő maga is a mainstream része lett. Az akkori brit miniszterelnök, Margaret Thatcher tanácsadója, később pedig förendiházi tag lett.

A pályája izgalmasan indult, ugyanis először helyszíni tapasztalatokat szerzett, és ebből merítve bizonygatta, hogy a fejlesztési segélyek nagyrészt hiábavalók, és nem

* A munka a KÖFOP-2.1.2-VEKOP-15-2016-00001 azonosítószámú, A jó kormányzást megalapozó közszolgálat-fejlesztés elnevezésű kiemelt projekt keretében működtetett Ludovika Kiemelt Kutatómühelyben, a Nemzeti Közszolgálati Egyetem felkérésére készült.

Pásztor Szabolcs a Nemzeti Közszolgálati Egyetem egyetemi adjunktusa és az Ethiopian Civil Service University (Etiópia), illetve a Kenyatta University (Kenya) vendégoktatója (e-mail: pasztor. szabolcs@uni-nke.hu).

A kézirat első változata 2019. június 19-én érkezett szerkesztőségünkbe.

DOI: http://dx.doi.org/10.18414/KSZ.2019.10.1093 
várt hatást eredményeznek. Ma már ezt a nézetet egyre többen képviselik, ugyanis empirikus úton, modellek segítségével igazolják azt, amit Bauer évtizedekkel korábban megsejtett. Bauert már csak ezért is tiszteletet érdemlő közgazdásznak tarthatjuk. Munkáját néhány évvel ezelőtt a közgazdasági Nobel-díjas Angus Deaton is elismerte azzal, hogy a 2013-ban megjelent, A nagy szökés címü könyvében Bauernek igazat adott (Deaton [2017]). Deaton leginkább azt emelte ki, hogy a segélyek „,hidraulikus” szerepének hangsúlyozása félrevezető: a szegénység felszámolása nem hasonlítható egy lerobbant autó megjavításához.

Bauer megítélése azonban korántsem (volt) ennyire egyértelmű. Nehéz feladatot vállalva, sokak érdekét megsértve kritizált egy olyan elméleti rendszert, amely abban az időszakban szinte megkérdőjelezhetetlennek tűnt. Megpróbálta ugyanis meggyőzni a segélyezési politika szakértőit, hogy az általuk képviselt elméletek és az általuk hozott intézkedések nincsenek összhangban a valósággal és a megalapozott gazdasági okfejtéssel. Bauer leginkább azzal érvelt, hogy a fejletlenség legfőbb oka az, hogy a gazdasági magatartás befolyásolásában félreértelmezik a már működő intézmények szerepét.

A tanulmány Bauer életútjának megértése és (át)értékelése érdekében öt nagyobb egységre tagolódik. Először Bauer kezdeti lépéseit kísérhetjük nyomon, és megérthetjük, hogy későbbi munkásságát milyen hatások befolyásolták. Majd tematikusan összegezzük Bauer nézeteit. Arra a kérdésre is választ keresünk, hogy ténylegesen miért nem (volt) népszerü Bauer munkássága, továbbá hogy elméleteinek van-e, volt-e érdemi hatása a közgazdasági gondolkodásra. Végül tanulmányunkat néhány következtetés levonásával zárjuk.

Nem titkolt célunk az, hogy felhívjuk a figyelmet a magyar közgazdasági gondolkodás egy méltatlanul elfeledett alakjára, és a hazai olvasóközönség elé tárjunk néhány olyan, Bauertől származó gondolatot, amelyek az idő próbáját kiállva egyrészt igaznak bizonyultak, másrészt pedig rendkívül elgondolkodtatóak.

\section{A gyarmati megbízottól a fejlödés-gazdaságtan legnagyobb kritikusáig vezető életút}

Bauer Péter Tamás 1915. november 6-án született Budapesten, jómódú családban. Az érettségi után a tanulmányait a Pázmány Péter Tudományegyetemen folytatta, ahol 1937-ben jogtudományi doktori oklevelet szerzett. 1937 és 1938 között a szegedi Ferenc József Tudományegyetemen jogot tanult, de szakmai pályafutása valójában 1934-ben kezdődött el, amikor 19 évesen Cambridge-ben beiratkozott a Caius College-ba. Erre az időszakra ő maga így emlékszik vissza:

„Édesapám bukméker volt Budapesten, és az egyik ügyfele ajánlotta neki, hogy a szorgalmas fia nagy hasznát vehetné a brit egyetemi oktatásnak, esetleg a cambridge-inek." (The Caian [1985] 33. o.)

Mivel semmilyen kapcsolata/kapcsolatuk nem volt még az országgal sem, Bauer egyszerủen megjelent Cambridge-ben fél tucat kollégium előtt 1934 márciusában. 
A képzésnek gyakorlatilag üres zsebbel, rendkívül gyatra angol nyelvtudással kezdett neki, és erre az időszakra úgy emlékszik, hogy „meglehetősen nehéz volt követni az előadásokat, de még a hétköznapi beszélgetéseket is”. Később bevallotta azt is, hogy „Cambridge-be érkezése előtt sohasem olvasott közgazdasági vagy gazdaságtörténeti témájú könyvet” (uo.).

A közgazdaságtannal azonban rögtön első kézből ismerkedhetett meg, ugyanis ahogyan azt Bod Péter Ákos kiemeli, Bauer Maynard Keynesnek néhány óráját is hallgatta, a klubjába is eljárt. Tutornak a talán szélsőségesen is baloldali Joan Robinsont kapta, aki ugyan segítőkész volt az indulásnál, de elfordult tőle, mert tanítványa nem osztotta a szovjet tervgazdaság iránti lelkesedését. Bauer inkább a piacgazdaságban látta a haladás megfelelő intézményét (Bod [2017]). A cambridge-i évek alatt Magyarországon is folytatta a megkezdett jogi tanulmányait, és „minden hosszabb vakációra” és karácsonyra hazaérkezett. 1937-ben Magyarországon teljesítette katonai szolgálatát is, majd jó egy évvel később az Egyesült Királyságba költözött.

A jog mellett közgazdaságtant tehát az angliai Cambridge-ben (1939-1940), majd később a University of Londonon tanult (1943-1946). A végzés után itt tanított agrárgazdaságtant (1947-1948), majd a Cambridge-i Egyetem egyetemi docense (19481956), később egyetemi tanára (1956-1960) lett.

Tagja volt annak a Mont Pélerin Societynek, amely közgazdászokból, filozófusokból, értelmiségiekből és üzleti vezetőkből álló, klasszikus liberális nemzetközi szervezetként leginkább a gazdasági liberalizmust és a libertariánus nézeteket vallókat fogta össze. Egészen a hetvenes évek végéig ez a társaság meglehetősen távol állt attól a fősodortól, amelyben akkor a keynesiánus és a jóléti állami dominanciája volt a meghatározó. Ennek tükrében talán meglepő is lehetett, hogy 1975-ben a Brit Királyi Akadémia tagjává választották, és akadémiai karrierje a továbbiakban (1960-1983) a London School of Economics közgazdászprofesszoraként folytatódott. 1983-ban II. Erzsébet angol királynő örökös förenddé nevezte ki (Lord Bauer of Market Ward), nem sokkal később vonult vissza a London School of Economicsről.

Bauer a fejlődés-gazdaságtan ${ }^{1}$ iránt nagyjából 30 évesen, a második világháború után kezdett érdeklődni. Basil Yamey, korábbi szerzőtársa és munkatársa szerint „egészen véletlen volt, hogy Bauer igazából e terület felé fordult" (Yamey [1987] 21. o.). A londoni Guthrie \& Co.-hoz került, amely a malajziai gumiipar területén tevékenykedett, s kutatási ösztöndíj segítségével behatóbban tanulmányozhatta ezt az iparágat, továbbá a brit gyarmati hivatal (British Colonial Office) malajziai megbízottjaként jelentést kellett készítenie kaucsukültetvényes kisbirtokokról (Yamey [1987]). E tapasztalatokból született 1948-ban az első könyve, amelynek címe a The Rubber Industry volt (Bauer [1948]). ${ }^{2}$

\footnotetext{
${ }^{1}$ Meier [1984] szerint, amíg a közgazdászok fejlődés iránti érdeklődése egészen Adam Smithig nyúlik vissza, a fejlődés-gazdaságtan (economic development) fogalmát az 1940-es évek előtt szinte alig használták.

${ }^{2}$ Yamey [1987] egy - valóban csak lábjegyzetben megjegyezhető - érdekességről számol be. James Gordon Farrell 1978-ban megjelent, The Singapore Grip című regényében nagyban épít Bauer könyvére, és úgy nyilatkozik, hogy az abban leírtak rendkívül értékesek voltak számára a Távol-Kelet 40 évvel azelőtti helyzetének bemutatásához.
} 
Ebben a munkájában Bauer bírálta a gyarmatok kormányait, hogy korlátozó intézkedéseikkel megnehezítették a kistermelők földhöz jutását. Úgy gondolta, hogy a föld elidegenítésének elutasítása különösen káros a kisbirtokosok számára, és megbontja a társadalmi összhangot. Könyvében így érvel:

„Annak érdekében, hogy az ültetvények létesítése megvalósítható legyen, a föld nagyvonalú elidegenítésének kell megvalósulnia [...] Különös figyelmet kell szentelni továbbá a kisbirtokok száma növelésének." (Bauer [1948] 348. o.)

Emellett kiemelte azt is, hogy a föld magánkézbe adásának halogatásával valószínűbbé válik a szélsőséges politikai mozgalmak megerősödése.

Néhány évvel később a brit gyarmati hivatal Nyugat-Afrikába küldte Bauert, hogy tanulmányozza a kereskedelmi tevékenységet és azon belül a monopolisztikus tendenciák érvényesülését. Szokatlanul hosszú és számos területre kiterjedő tanulmány született: az 1954-ben publikált, West African Trade című kötet. Ez a mü tökéletesen bemutatta Bauer sokirányú tehetségét. Rendkívül gyakorlatias volt, hiszen egyrészt az olvasóit valósággal elárasztotta tényekkel, másrészt pedig vitába szállt számos közgazdasági tévedéssel. Malajzia és Nyugat-Afrika tanulmányozása után úgy vélekedett, hogy

„...az absztrakciókat egészen szükre kell szabni, és fel kell tárni azokat a tényezőket és hatásokat, amelyeket a modern közgazdaságtanban intézményi tényezőknek (vagy a közgazdászoknak adott adatoknak) gondolunk. Az ilyen vizsgálat néhány olyan tényező átértékelését jelenti, amelyeket a modernebb közgazdasági tankönyvekből egyszerüen kihagynak, még az olyanokból is, amelyek bevallottan az alkalmazott közgazdaságtannal foglalkoznak." (Bauer [1954] 3. o.)

Bauer az önellátásról a piaci cserére való áttérés néhány olyan szempontját dokumentálta, amely addig ismeretlen volt, vagy egyszerüen kimaradt az akkori ortodox fejlődés-gazdaságtanból. Ő maga talán az egyik legalaposabb olvasója volt Adam Smith fő művének, és az a tény, hogy Adam Smith az ember mint kereskedő szerepét hangsúlyozta, jelentősen befolyásolta gondolkodásmódját. Tapasztalatai alapján megbizonyosodott arról, hogy ha a joguralom és a biztonság keretei adottak, a gyarmatokon gazdálkodók - a szerényebb iskolai végzettségük dacára - éppen úgy reagálnak a keresletre, mint a nyugati országokban élők. A mezőgazdasággal foglalkozók képesek voltak hosszú távon való gondolkodásra, ugyanis olyan növényeket ültettek, amelyek sok-sok év elteltével fordultak termőre, megfelelően reagáltak az árak változására és a piaci ösztönzőkre. A saját kínálati görbéjük nem hajlott visszafelé. ${ }^{3}$ Elkan és szerzőtársai [1982] megjegyzi, hogy Bauer korai munkái előrevetítették az informális szektor feltérképezését:

„Azt hiszem, hogy Bauer volt az első közgazdász, aki leírta annak a jelenségnek a gazdasági jelentőségét és nagyságát, amelyet ma informális szektornak hívunk." (Yamey [1987] 22. o.)

${ }^{3}$ Krueger [1997] Theodore Schultzot említi, aki a tradicionális mezőgazdaságot tanulmányozva megjegyezte, hogy a földművesek igenis reagálnak a piaci változásokra (Schultz [1964]). Viszont Bauer a személyes tapasztalataira alapozva mindezt már évekkel korábban leírta (Bauer [1948], [1954]). 
A West African Trade megjelenése után Bauer a gazdasági fejlődés körül kialakuló vita kereszttüzébe került. Attól eltekintve, hogy e kutatások egyik úttöröje volt, Bauerre már a kezdetektől csak marginalizált gondolkodóként tekintettek. Ennek pedig leginkább az volt az oka, hogy ő más irányelveket képviselt. Szerinte a gazdasági növekedéshez alapvetően az egyén szabadságára és a saját intuícióinak követésére van szükség, nem pedig arra, hogy a kormányzat képviselői valamilyen irányt szabjanak a társadalomnak. Bauer azok közé tartozott, akik nem ambicionálták a társadalom szerkezetének megváltoztatását (social engineering). Ez természetesen nem tette őt népszerüvé abban az időszakban, amikor a gazdasági fejlődést érintő gondolkodást a központi tervezés dominálta, annak ellenére, hogy fő képviselői vagy nem, vagy csak nagyon rövid ideig éltek fejlődő országokban. Bauer pedig malajziai és nyugat-afrikai tapasztalatok mellett a karibi térségben és Indiában szerzett tapasztalatai alapján igyekezett ellentmondani az akkori korszak uralkodó közgazdasági narratívájának. Rendkívül árnyalt írásai és előadásai állításait a terepen szerzett tapasztalataira építette.

Bauer első elemzései némileg más kérdéseket feszegetnek, mint a későbbiek (Bauer [1984] 1. o.). Az első munkái a malajziai és a nyugat-afrikai megfigyelései alapján születtek, így ír róluk:

„....mind a két esetben, még mielőtt Délkelet-Ázsiába és Nyugat-Afrikába érkeztem volna, tudtam, hogy ezek a gazdaságok annak ellenére gyorsan fejlődtek, hogy ekkor még gyarmatok voltak [...] nem volt szükség komolyabb fejlödés-gazdaságtani tanulmányokra ahhoz, hogy tudjuk, hogy 1885 előtt egyetlen kaucsukfa sem volt Malajziában, és egyetlen kakaófa sem volt Brit Nyugat-Afrikában. Az 1930-as évekre a kaucsukot, a kakaót és az egyéb exportnövényeket több millió hektáros területeken termesztették, és ezek nagy részét nem európaiak müvelték." (Bauer [1984] 2. o.)

Bauer ebből azt a következtetést vonta le, hogy a malajziai és a nyugat-afrikai gazdaságok, annak ellenére, hogy az európai közgazdászok nézőpontjából fejletlenek voltak, valójában képesek voltak a dinamikus növekedésre.

„A fejlett infrastruktúra legkevésbé sem volt előfeltétele a délkelet-ázsiai és a nyugat-afrikai gazdaságok mezőgazdasági termékbővülésének [...], de még a munkaerő toborzásának sem; az eredmény leginkább az erőforrások kényszerủ mozgósításának volt köszönhetö." (Bauer [1984] 4. o.)

Ennek a két munkának az volt a végső következtetése, hogy a gazdasági környezet jóval gazdagabb és komplexebb, mint ahogyan azt jellemzően képzelték. A West African Trade címü könyvének - amely sok szempontból az egyik legambiciózusabb empirikus munkája - elolvasása után azonnal láthatjuk, hogy Bauer megértette Vilfredo Pareto elméletének központi alapelvét, amely a gazdasági jelenségek kölcsönös függőségéről szólt. A munkássága során ezt sohasem mellőzte.

A későbbiekben - ahogyan arra például Bod [2017] pontosan rámutat - beszédeiben a segélyezés kultúráját és a sokak által haladónak gondolt jóléti államot nemcsak közgazdasági, hanem etikai alapon is bírálta. Mindkettő növeli az államtól való függést, az élet átpolitizálásával pedig konfliktusokat gerjeszt, és 
aláássa a demokratikus kohéziót. Az általa képviselt elveket sokan nem osztották, és a Margaret Thatcher miniszterelnökhöz füződő tanácsadói kapcsolata, baráti viszonya - mint reakciós és piaci fundamentalistát - még inkább a baloldal céltáblájává tette. A baloldali The Guardian nekrológjában a harmadik világ fejlesztési segélyezésének legbőszebb thatcheriánus ellenzőjeként említi, akinek a nézetei régimódiak és jobboldaliak. Bauer kétségkívül szókimondóan a nyugati baloldali értelmiség, valamint a nemzetközi segélyek, transzferek elosztásában érdekeltek szemére vetette a büntudat érzésének $s$ a piacellenes hangulatnak a fenntartását, ezért megpróbálták őt szélsőséges piacpártinak, a jövedelmi egyenlőtlenségek iránt érzéketlennek beállítani. Bauer viszont jól látta, hogy a fejlődő világ kormányai ügyesen „rájátszottak” az úgynevezett koldusattitüdre, és gyakran színlelték az elesett szerepét, amely kellő meghallgatásra talált a sokszor bủntudatot érző nyugati kormányoknál.

\section{A fejlődés-gazdaságtan premisszái a posztkolonialista időszakban és Bauer kritikája}

A posztkolonialista időszakban a baloldali gazdaságképet valló közgazdászok uralták a fejlődéselméleti irányzatokat, nekik volt a legerősebb befolyásuk a nemzetközi segélyek és a fejlesztési programok alakítására. Bauer tehát már a kezdetektől fogva rendkívül erős ellenszélben fejtette ki szakmai álláspontját. Bod [2017] úgy fogalmaz, hogy Bauernek nem igazán voltak követői, és nézetei a korszak elfogadott gazdasági és politikai irányzataival álltak szemben. Különösen Balogh Tamás, Káldor Miklós és Gunnar Myrdal piacellenes elméleteit bírálta. Ahogyan azt a következőkben látni fogjuk, következetesen megcáfolta a központi tervezés és a fejlődés-gazdaságtan területén akkoriban széles körben elfogadott tökefelhalmozás (primitive accumulation) elméletét. Később pedig a két elmélet tudományos alapot teremtett a szegénység ördögi körének (vicious circle of poverty) érveléséhez, amelynek hamisságára Bauer folyamatosan felhívta a figyelmet.

\section{A központi tervezés bírálata}

A baloldali és piacellenes gazdaságpolitikai narratíva hatására a posztkolonialista időszak elején jelentős mennyiségü külföldi segély áramlott a szegényebb országokba, aminek elsődleges célja a tőkeállomány nagyságának növelése volt. $\mathrm{Az}$ alapvetés viszonylag egyszerủen hangzott: ha a tőkét megfelelően fektetik be, akkor a nagyobb tőkebefektetések növelik a dolgozók produktivitását, és a nagyobb termelékenység magasabb jövedelmet is jelent. A recept szerint tehát a szegényebb országokban jelentős transzferekre volt szükség ahhoz, hogy megfelelő tőke álljon rendelkezésre a növekedés előmozdításához. Számos fejlődő országban általános elméleti igazolássá vált az egyre aktívabb állami beavatkozást legitimáló keynesi közgazdaságtan, és minden határon túl azt hangsúlyozták, 
hogy a gazdasági növekedés megteremtésében a tőke felhalmozása kiemelten fontos. ${ }^{4}$ A központi tervezés szerepe így látványosan felértékelödött, és ahogyan azt majd látni fogjuk, a második világháború utáni gazdasági fejlődést érintő kérdésekre jelentős befolyást gyakorolt a marxizmus is. Bauer ezekre egyfajta válaszul egy teljesen más, sokak szerint észszerübb megoldást kínált.

A központi gazdaságtervezés során a kormányzati döntéshozatal helyettesíti a magánszektor döntéshozatalát, és Bauer - dacára annak, hogy Keynes előadásait is hallgathatta - munkásságában sohasem tudott elszakadni ennek bírálatától:

„A tervezés nyilvánvalóan vonzó a politikusok, a hivatalnokok és az értelmiségiek számára, ugyanis olyan hatalmi pozíciók születnek, amelyeket ezen csoportok tagjai kívánnak betölteni. Ezekért pedig politikai, emocionális és pénzügyi előnyöket várnak." (Bauer [1978] 185. o.)

Azt vallotta, hogy a kormányzati képviselők kezében lévő hatalom sokkal veszélyesebb, mint a gazdagok kezében lévő vagyon. A tőkeáramlás és az utazás korlátozása a szegényebb rétegeket is sújtja. Éppen emiatt hangsúlyozta Bauer, hogy

„....a harmadik világban - éppen úgy, mint Nyugaton - a piacok által teremett lehetőségek növekedése kiemelten fontos a szegényebb rétegek számára. [...] a szegénység nem azonosítható a szabadság hiányával, abban az értelemben, hogy az az egyén mások általi kényszerítésének tárgya lehet. [...] a piaci rend a szükséges feltétele az egyéni szabadságnak." (Bauer [1984] 125-126. o.)

Ő maga megértette, hogy miért lett vonzó a központi tervezés, ugyanis hamar rájött, hogy sokan félreértelmezik a piaci rendszert, és „irracionálisnak, zavarosnak” gondolják, míg a tervezés „meghatározott módszeren, tudományos alapokon és elgondoláson nyugszik" (Bauer [1978] 185. o.).

Ennek tükrében érthető, hogy Bauer idejében miért volt széles körben elfogadott az az elképzelés, hogy a szocialista tervezők jobban meg tudják oldani a szegénység problémáját, mint maga a szabadpiac. Ezt a nézetet pedig többnyire a fejlődés-gazdagságtan nyugati szakértői terjesztették. 1957-ben például Paul A. Baran, a Stanford Egyetem professzora így írt:

„A szocialista tervgazdaság létrehozása a fejlődő országokban alapvető és nélkülözhetetlen a gazdasági és társadalmi haladás eléréséhez." (Baran [1957] 261. o.)

A meggyőződés megerősítését szolgálja Gunnar Myrdal is, amikor egy évvel korábban így vélekedik:

„A fejlődő országok azon különleges tanácsadói, akik nem sajnálták sem az időt, sem a fáradságot, hogy megismerjék a valós problémákat [...], mindahányan a központi tervezést javasolják a fejlödés első feltételeként." (Myrdal [1956] 201. o.)

\footnotetext{
${ }^{4}$ Alapvetően furcsa paradoxon a keynesi közgazdaságtant hangsúlyozni ebben a kérdésben, hiszen annak elsődleges szerepe a ciklikus ingadozások ellensúlyozásában volt, nem pedig a preindusztriális gazdaságok növekedési alapjainak megteremtésében.
} 
Bauer szemében a tervezés mantraszerű ismételgetése „a marxizmus-leninizmus mindent átható messianisztikus hitvallása” volt. Szerinte a „piactagadó központi tervezők” olyan közgazdászok voltak, akik árak és költségek figyelembevétele nélkül gondolkodtak, és csak a felülről irányított (top down) gazdaságfejlesztésre fókuszáltak. Ezzel a szemlélettel pedig teljes egészében figyelmen kívül hagyták a gazdasági élet legfontosabb építőkockáit, vagyis féloldalas megoldást kínáltak. Bauer rámutatott ugyanis, hogy a növekedés szempontjából a tőkefelhalmozás egyoldalú hangsúlyozása túlzottan leegyszerüsítő, és korántsem a teljes kép:

„...a tervezés szakirodalmában, különösen a marxista-leninista irodalomban, a gazdasági növekedésre úgy tekintenek, hogy figyelembe sem veszik az általános életszínvonalat, és csak az ipari fejlődés kap hangsúlyt. [...] A nagyszabású iparosítás támogatói, ezen belül is a nehézipar erőteljes fejlesztésének szószólói, szinte sohasem szólnak az árakról, a jövedelmekről, a költségekről, a keresletről, és az életszínvonalról.” (Bauer [1976] 172. o.)

Bauer leszögezte továbbá, hogy a fejlődés nem az ipari termelés fejlesztésétől függ, az ipari termelés pedig nincs kapcsolatban a központi tervezés mantraszerü hangsúlyozásával. Szerinte aki máshogyan vélekedik, az nem veszi figyelembe a gazdaságtörténetet, és összekeveri a korrelációt az okozattal:

„...az iparosítás melletti érvelés úgy hangzik, mint amikor a drága szivarok elszívása tesz valakit gazdaggá, ugyanakkor általában a gazdagabbak azok, akik drága szivarokat fogyasztanak. [...] a szegényebb országokban a mezőgazdaságtól való függésnek számos oka van, ezek közül például azt lehet kiemelni, hogy az eladásra kínált mezőgazdasági termékek előállítása jelenti a leghatékonyabb módját az erőforrások használatának a magasabb életszínvonal felé vezető úton.” (Bauer [1972] 144. o.)

Ma már tudjuk, hogy az importhelyettesítő iparosítás leginkább a mezőgazdaság szerepét értékelte le, és más növekedéstorzító gazdasági visszásságokat is hozott. Azon kelet-ázsiai országok, amelyek felhagytak a modellel, igazolták Bauer meglátásait, de sajnálatos módon azok is mellette szóltak, amelyek nem.

Bauer felismerte azért, hogy a hatalmas kormányközi transzfereknek (fejlesztési segélyeknek) van pozitív hatásuk is, ugyanis jól látta, hogy ezek a források egyrészt a népesség meghatározott csoportjait gazdagítják, másrészt pedig bizonyos területeken valóban katalizátorai lehetnek a gazdasági fejlődésnek. Szerinte hibát akkor vétünk, amikor egy meghatározott fejlődést, például az iparosítást, a teljes gazdaság fejlődésével azonosítunk, amely egyébként növekvő életszínvonalat jelent.

„Az állami tervezés növelheti az elérhető források nagyságát a gazdaság megfelelő szektoraiban, de ez természetesen csak más tevékenységek kárára történhet. Ennek azonban semmi köze sincs a teljes gazdaság expanziójához. Ezt teljesen elhomályosítja az a mindent átható gyakorlat, amely szerint egyetlen szektor kibocsátását és fejlődését a teljes gazdasággal azonosítják. Ezt a gyakorlatot pedig leginkább azon közgazdászok és hivatalnokok követik, akik figyelmen kívül hagyják a költségeket.” (Bauer [1977] 149. o.)

Bauer élesen bírálta azt a fejlődési szakértők által széles körben elfogadott érvelést, mely szerint nagyszabású kormányzati beruházásokra van szükség ahhoz, hogy 
csökkenjen a szegénység. Elöször kiemelte, hogy a beruházás csak egyetlen olyan tényező, amely befolyásolja a gazdasági növekedést. Bauer egészen pontosan így érvel:

„Félrevezetö azt gondolni a beruházásokról, hogy azok a fejlődés legfontosabb meghatározói. Más tényezők és befolyásoló elemek, mint például az intézményi és politikai erők, a népesség képességei és attitüdje, a kiegészítő erőforrások kínálata gyakran hasonlóan fontosak, sőt még fontosabbak is. [...] Több értelme van azt mondani, hogy a tőke a fejlödés folyamata során teremtődik meg, mint azt, hogy a fejlődés a tőke függvénye. [...] Ha a tőke kivételével a fejlődés minden feltétele adott, akkor a töke vagy helyi szinten teremtődik meg, vagy a külföld bevonásával kereskedelmi alapokon áll majd rendelkezésre a kormányzat és a magánszféra számára. Utóbbinak forrásai a magasabb adóbevételek lesznek vagy a vállalkozásoknál képződő nyereségek. Ha azonban a fejlődés feltételei nem állnak rendelkezésre, akkor a segélyezés, amely ilyen körülmények között az egyetlen külső tőkeforrás, szükségszerüen terméketlen és hatástalan lesz.” (Bauer [1957] 119. o.)

Személyes tapasztalatai alapján a West African Trade című könyvében - még tovább árnyalva a képet - azt is hangsúlyozta, hogy a nagyobb tőkemennyiség önmagában nem csodaszer:

„....mivel a helyi technikai és adminisztratív készségek szűkösek, a termelési eszközök hiányának negatív hatása egyre erőteljesebb, tehát nem csak a tőke hiánya az, ami viszszaveti a fejlődést." (Bauer [1954] 13. o.)

Bauer úgy vélekedett, hogy „a szegénység oka nem a pénzhiány [...], a pénz a gazdasági tevékenység eredményeként áll elö, nem pedig annak feltételeként" (Bauer [1987] 6. o.). Később amellett érvelt, hogy amire igazából szükség van, az „az anyagi gazdagodást hátráltató attitűdök és szokások megváltoztatása, a készségek megteremtése a piac kiszolgálására (az önellátás helyett) és a megfelelő gazdaságpolitikai intézkedések meghozatala. A tőkefelhalmozás nagy része nem előfeltétele az anyagi gyarapodásnak, hanem a velejárója. A lakhatás egy jó példa [...] az infrastruktúra (utak, vasutak és hasonlók) eszközök és berendezések összessége, amelyek nem megelőzik vagy meghatározzák a fejlődést, hanem megjelennek a tartós fejlődési pálya következtében.” (Bauer [1981] 248. o.)

Azt sem tartotta egészségesnek, amikor az állam adókat és más intézkedéseket vezetett be a magánfogyasztás csökkentése és a tőkefelhalmozás érdekében. Szerinte ekkor a társadalom jóléte csökken: a magánbefektetések visszaesnek, ami visszaveti a piaci szektor növekedését, a kötelező megtakarítás pedig csökkenti az egyén szabadságát.

„Nem helyénvaló, hogy úgy véljük, a kötelező megtakarításokból származó bevételek [...] az erőforrások nettó növekedésének számítanak. Ebben az esetben egy sajátos költség jelenik meg, amely nem más, mint az a kieső nettó jövedelem, amely akkor állt volna elő, ha a forrásokat a magántőke felhalmozására fordították volna. Sőt a fejlődés érdekében történő adóztatás leginkább a kereskedelem szektorát érinti, és nagy valószínűséggel olyan formákat ölt, amely visszafogja a termelés kereskedelemi szempontú növekedését." (Bauer [1957] 116. o.)

Bauer megjegyzi azt is, hogy az állam által irányított befektetések közismerten nem hatékonyak, ugyanis azokat politikai és nem gazdasági megfontolások vezérlik. 
A fejlesztéspolitika szakértőinek úgynevezett befektetési fétise (investment fetish) számtalan nagyszabású projektben öltött testet, amely igazából a kormányzó elit monumentális alkotása maradt a szegények rovására (Bauer [1981]). Ráadásul a magántulajdonra vonatkozó jog hiánya ezen beruházások esetében rossz gazdálkodáshoz és fenntartáshoz vezetett.

„Az állam által irányított befektetéseknek és a kötelező megtakarításnak negatív hatása van a szabadságra is: ezek jellemző módon az országon belül a hatalom eloszlásának nagyfokú egyenlötlenségét eredményezik, ami beszűkíti azon szereplők választási lehetőségeit, akik felett a hatalmat gyakorolják." (Bauer [1957] 124. o.)

Amiben a legnagyobb problémát látta Bauer, az nem az erő használata a tulajdonjogok biztosítása érdekében, hanem inkább az, amikor a kormányzat a tulajdonosok beleegyezése nélkül veszi át a tulajdonjogot valamilyen politikailag meghatározott jövedelmi vagy vagyoni egyenlőség elérése érdekében. Minél jobban halad elöre egy ország a redisztributív vagy a jóléti társadalom felé, annál nagyobb lesz a hatalom egyenlötlensége, ami abból adódik, hogy a politikai döntések győzedelmeskednek a piaci erők fölött (Bauer [1957] 125. o.).

\section{Bauer mint a piacellenes nézőpont legharsányabb bírálója}

Ahogyan a korábbiakban láthattuk, amikor a legtöbb fejlesztési szakértő piactagadó, állam által irányított fejlesztési politikában gondolkodott, Bauer már a kortársai előtt járt, és megértette a gazdasági szabadság, ezen belül a tulajdonjog jelentőségét. Ezeket a személyes szabadság és a gazdasági növekedés kulcstényezőjének tekintette.

Bauer az elsők között látta azt is, hogy a fejlődő országok igazi problémája nem a piaci kudarc volt, hanem a kormányzati kudarc. ${ }^{5}$ Erről így írt:

„A piaci kudarc szakirodalmát leginkább egyfajta korbácsként használják, amellyel a piaci rendszert csépelik. Azon kritikusok, akik a piaci rendszert politikai (központi) döntésekkel helyettesítenék, ritkán teszik fel maguknak a gazdasági hatalom politikai kezekben való összpontosulásának, a választási lehetőségek beszükülésének, a politikusok és a bürokraták tényleges céljainak és a társadalomban rendelkezésre álló tudás minőségének, mértékének és átadásának kérdéseit." (Bauer [1984] 30. o.)

„....az a vélekedés, hogy gazdasági ellenőrzésre van szükség ahhoz, hogy megvédjük az egyént a piaci kockázatoktól, különösen az exportra szánt termékek áringadozásaitól, igazából a piaccal szembeni ellenségeskedés egyfajta megjelenési formája volt. [...] az állami ellenőrzések semmilyen értelemben nem biztosítottak stabilitást a gazdák vagy azon gazdasági szereplők számára, akikre vonatkoztak. Mind az ellenőrzés, mind pedig a gazdasági élet ebből következő átpolitizálódása sokkal súlyosabb és kevésbé előrejelezhető veszélyeket rejtett magában, mint a piac. Igazából, ha a mezőgazdasági árak ingadoznak, a termelőknek megvan a lehetőségük arra, hogy tartalékoljanak. Semmiféle ilyen védelem nincs abban az esetben, amikor visszavonják a kereskedelmi engedélyt, elkobozzák a jövedelmet, a vagyont, vagy kitoloncolás történik." (Bauer [1978] 184-185. o.)

\footnotetext{
${ }^{5}$ Jól mutatja ezt például többek között a mai szomáliai helyzet (Marsai [2015]).
} 
A piaci pesszimisták implicit feltételezése abban az időben az volt, hogy a kormányzati képviselők egyszerüen jobbak, mint a piaci erők. Ahogyan azonban arra Bauer ráirányítja a figyelmet, a kormányzat szereplői hatalmuk révén élhetnek kényszerítő jogukkal, a piaci szereplök azonban nem:

„Az utóbbi években a piaci erők ellenzői a politikai nyomás számos példáját mutatták, vagy kiemelték a piaci szereplők csalárd húzásait. Talán jobb lenne a társadalom számára az, ha több ilyen habitusú ember lenne a kormányzati szektorban, és ők mindannyian birtokolnák azt a kényszerítő erőt, amely ezzel jár?” (Bauer [1984] 29. o.)

Bauer válasza természetesen nemleges volt, és kiemelte, hogy akik a tökéletlenségei miatt kritizálják a piacot, nem veszik figyelembe a tényt, hogy a „piaci szereplők emberek [...], és a döntéseik nem mindig lehetnek hibátlanok” (uo.).

Bauer azt is hangsúlyozza, hogy nem lehet az anyagi fejlödés elmaradását a piac számlájára írni, nem is beszélve az általános boldogság és a megelégedettség hiátusáról. Valójában az önkéntes döntések következménye, hogy az egyén anyagi szempontból megreked-e egy bizonyos szinten, vagy a gazdasági növekedés költségeit túlzónak tartva megelégszik egy alacsonyabb életszínvonallal. „A piaci erők lehetővé teszik számára, hogy megvalósítsa önmagát..." (Uo.)

A piaci erők bírálói hamar előhúzták a legfontosabb kártyájukat, és Bauert a jövedelmi egyenlőtlenségek kapcsán érzéketlennek bélyegezték. Köztudott tény volt már akkor is, hogy a piaci erők a vagyoni és jövedelmi egyenlőtlenségek növekedéséhez vezettek/vezetnek. Bauer ezzel a kritikával szemtől szemben lépett fel, és rendkívül sarkos véleményében elöször is megkülönböztette az egyenlőtlenséget (inequality) és a különbséget (difference), és leginkább az utóbbi kifejezést használta (azt kevésbé tartotta érzelmesnek). Mindig azt hangsúlyozta, hogy az egyének eltérnek egymástól képességeikben, jellemvonásaikban és magatartásukban, és ezek a különbségek a jövedelmeikben és a vagyonaikban is testet öltenek. Másodszor rámutatott arra, hogy a piacon az egyén akkor indulhat el a gazdagodás útján, ha kiszolgálja mások igényeit, vagyis kielégíti mások fogyasztói preferenciáit. Azok, akik magasabb értékü célokra fordítják erőforrásaikat, természetszerüen jobban teljesítenek, mint azok, akik nem. Harmadszor pedig kiemelte, hogy kétféleképpen lehet magasabb jövedelmi szintet elérni: kényszerítéssel vagy önkéntes cserével. Erre reflektálva azonban sietve kiemelte, hogy a piaci liberalizmus igazi veszélye egyrészt az, hogy a jövedelmi különbségek miatt kiigazító kormányzati intézkedésekre van szükség, másrészt pedig az, hogy a Nyugat felelős vagy bünös a fejlödő világ szegénységéért (Bauer [1981] 4. fejezet).

Az valóban igaz, hogy a társadalmi igazságosság nagyobb jövedelmi és vagyonbeli egyenlőséget feltételez, ami azt vonja maga után, hogy a jövedelemben és a vagyonban jelentkező markáns különbségek a kizsákmányolásnak, az elnyomásnak, a diszkriminációnak vagy a nem megfelelő jogosultságoknak köszönhető. Ilyen értelemben pedig a politikailag vezérelt redisztribúció kívánatos lenne, de az irigység ilyesfajta legitimizálása Bauer szerint a nyílt társadalmak legnagyobb veszélye (Bauer [1984] 73. o.).

Ezzel kapcsolatosan inkább úgy vélekedett, hogy a jövedelmi különbségek (egyenlötlenség) mérséklése szükségszerűen magával hozza a kényszerítés eszközét, ezért a nyílt társadalmak egyenlősítő kezdeményezéseiben alapvető ellentmondást látott: 
„A nyílt és szabad társadalomban az a politikai fellépés, amely szándékosan azzal a célzattal lép fel, hogy minimalizálja vagy teljesen el is tüntesse a jövedelmi és vagyoni különbségeket, olyan mérvű kényszerítést von maga után, amely után a társadalom már nem lesz többé nyílt és szabad. A gazdasági egyenlőség keresésének sikerességéért a társadalomnak a hatalom jóval nagyobb egyenlőtlenségét kell felvállalnia az uralkodók és az alárendeltek között.” (Bauer [1981] 8. o.)

Számos legkevésbé fejlett ország tanulmányozása után Bauer arra a megállapításra jutott, hogy a gazdasági növekedés az intézményektől, a kultúrától, a politikai vezetéstől, nem pedig a tervezéstől, a nagyszabású beruházásoktól és a természeti erőforrásoktól függ:

„A gazdasági növekedés személyes, kulturális, politikai tényezőkön nyugszik, továbbá az egyének alkalmasságán, motivációján és a társadalmi és politikai intézményeken. Ahol ezek kedvezők, a tőke helyi szinten áll rendelkezésre, vagy külföldről áramlik be, és ha szűkösen állnak rendelkezésre a földterületek, az élelmiszert intenzív gazdálkodás révén vagy más termékek exportjával szerzik be.” (Bauer [2000] 29. o.)

Bauer azzal is érvelt, hogy a nagy és növekvő népesség, de még a magas népsürüség sem feltétlenül káros a gazdasági növekedés szempontjából akkor, ha az intézményi struktúra kedvező az egyéni szabadság és felelősség szempontjából. Szerinte „a gazdasági teljesítmény és növekedés az egyének gazdasági magatartásától függ, nem pedig a számuktól" (Bauer [2000] 30-31. o.) Kritizálta az egy före jutó jövedelem használatát a jólét mérése szempontjából, ugyanis az

„figyelmen kívül hagyja azt a megelégedettséget, amelyet az egyén abból merít, hogy több gyermeke van, vagy esetleg tovább él. [...] Ironikus módon egy további gyermek megszületésével az egy före jutó jövedelem csökken, míg egy borjú megszületése fejlödésnek tekinthető." (Uo.)

Bauer úgy vélte, hogy a megszorító migrációs és népesedési intézkedések jólétcsökkentő hatásúak.

\section{A szegénység ördögi körének éles bírálata}

Bauer küzdött az ellen a közvélekedés ellen is, amely szerint a fejletlenség visszatérő és kumulatív folyamatokat stimulál, tartósítva a gazdasági elmaradottságot, lehetetlenné téve a szegénység ördögi köréből való kitörést. Hangsúlyozta, hogy a szegénység ördögi körének elmélete alapvetően hibás, olvasatában a szegénység nem lehet egy körkörös folyamat. Bauer rámutatott, hogy azt megelőzően is léteztek valóban gazdag országok, amelyek mindegyike

„....korábban szegény volt, alacsony egy főre jutó jövedelemmel és alacsony tőkefelhalmozási fokkal. Ezek a tényezők pedig nagyon jól jellemzik a jelenlegi fejlődő országokat. [...] A mai fejlett országok mindenféle számottevő külső tőke és támogatás nélkül indultak fejlődésnek, ami a szegénység ördögi köre és a stagnálás tézise szerint teljességgel lehetetlen lett volna." (Bauer [1976] 165. o.) 
Bauer [2000] szerint ha a szegénység ördögi körének nézete helytálló lenne, akkor az emberiség még mindig a paleolitikumban élne.

Bauer világosan látta a szegénység ördögi körének és a fejlesztési segélyezésnek a kapcsolódási pontját. Erről a kérdésről így vélekedett:

„A szegénység ördögi köréhez való állandó ragaszkodás és a fejlődő országok gazdasági stagnálása népszerüvé tette a fejlesztési segélyezést, amely sokak számára a politika legfontosabb tárgya lett." (Bauer [1965] 17. o.)

A segélyezésnek igazából akkor van értelme, ha a tőkehiány olyan méreteket ölt, hogy a helyi lakosság azt sohasem lenne képes csökkenteni, sem takarékoskodással, sem pedig a kereskedelemből származó nyereség befektetésével. Bauer szerint a feltételezésnek egyértelmü marxista jegyei vannak, mert az iparosítás ezek szerint csak évszázados rablás és kizsákmányolás eredményeképpen jöhetett létre.

Bizonyos értelemben Bauer az antikapitalizmus ördögi körére mutatott rá. A fejlődő országokban látható fejletlenséget többé-kevésbé marxi mintázatként interpretálják, amely valójában a Nyugat akciójából (kereskedelem) és tehetetlenségéből (a támogatás és a segélyezés hiányából) eredő károk összege. A nyugatiaknak ez a fajta büntudata kényszeríti ki a fejlesztési segélyezés politikáját, amely egyrészről a szegények megadóztatását jelenti a gazdagabb országokban, másrészről pedig a szegény országokban élő gazdagabb réteg jövedelmének kiegészítését. A donor országok a tőkefelhalmozás fontosságát hangsúlyozták, de hajlamosak voltak elfelejteni a fogadó országok valós körülményeit. Bauer olvasatában a fejlesztési segélyek ezáltal nem húzzák ki az egyes országokat a szegénységből - újra ugyanabba a körbe lépünk.

\section{A fejlesztési segélyezés legharsányabb ellenzöje}

A posztkolonialista időszakban a fejlesztési segélyezés kapcsán a konszenzusos megközelítés egészen egyszerü volt: inkább segélyezz, mint kereskedj! Bauer [1981] szerint a nyugati országokban, függetlenül azok gazdagságától és ideológiai álláspontjától, a tengerentúli fejlesztés (overseas development) a politikai vitán felül emelkedett, és az állami kiadások legkevésbé megkérdőjelezett formájává (least questioned form) vált. Azokat az országokat pedig, amelyek a nemzeti jövedelmük nagyobb részét fordították fejlesztési segélyezésre, jobban teljesítőknek hívták. Bauer azzal érvelt, hogy

„[A] harmadik világ kifejezés, illetve annak előzményei és az olyan szinonimái, mint a fejletlen világ, a kevésbé fejlett világ és a fejlődő világ, ráadásul most már a Dél is, egyfajta gyakorlati célt szolgál azon országok megjelölésére, amelyek kormányai - kevés kivétellel - fejlesztési segélyeket kérnek és kapnak a Nyugattól. A harmadik világ és a Dél fogalma, illetve a fejlesztési segélyezés politikája elválaszthatatlan egymástól. Igazából ezek ugyanazon érme két oldalát jelentik. A harmadik világ fogalma a fejlesztési segélyezés eredményeként született: fejlesztési segélyezés nélkül pedig nem is létezne."

(Bauer [1984] 40. o.) 
Bauer ezt a megközelítést sohasem tudta elfogadni, és a kormányok közötti transzferekre (a fejlesztési segélyekre) úgy tekintett, mint a piaccal szemben megnyilvánuló ellenségeskedés forrásaira. A fejlesztési segélyekkel kapcsolatos szembenállása - amelyekről egyébként széles körben azt gondolták, hogy a kevésbé fejlett országokban serkenti a tőkefelhalmozást - a különböző gazdasági jelenségek összefüggéseinek feltárásán, megértésén és nem utolsósorban a gyakorlatban szerzett tapasztalatain nyugodott. Leginkább amellett érvelt, hogy a fejlesztési segély egyfajta olyan szubvenció, amit korrupt kormányok kapnak - de legkevésbé sem a szegények. Szerinte a fejlesztési segélyek nem is szükségesek és nem is elegendők a gazdasági fejlődéshez, és többnyire inkább károsak (Bauer [1976]).

Később amellett érvelt, hogy a harmadik világban a politikai vezetők arra használják a külső segélyeket, hogy a gazdasági életben nagyobb ellenőrzést szerezzenek.

„Mivel a fejlesztési segélyeket a kormányok kapják, ezért megerősödik és tovább is bővül az állami szektor a magánszféra rovására. [...] a külföldi segélyek politikai feszültségeket idéznek elö, illetve súlyosbítják is azokat, ami ismételten a piacba vetett hitet veti vissza, különösen a többnemzetiségü társadalmakban.” (Bauer [1978] 182-183. o.)

Bauer a munkáiban a fejlesztési segélyekre gyakorlati hatásuk kapcsán minden alkalommal markáns piacellenes erőként tekintett.

„Bármi is történjen a recipiens országokban, az mindenkor hivatkozási alapként szolgálhat a segélyezés fenntartásának vagy kiterjesztésének támogatására. A fejlődés a segélyezés hatékonyságának bizonyítéka, ezért ha elmarad a növekedés, a bővítése melletti érvelés egyszerüen annyit jelent, hogy a fejlesztési támogatások nem elegendők, és azok menynyiségét növelni kell. Néhány támogató azzal érvel, hogy célszerütlen lenne a segélyek megtagadása a gyorsan fejlődőktől, mások pedig arra mutatnak rá, hogy kegyetlen lenne azt megtagadni a rászorulóktól. A fejlesztési segélyek ezáltal olyanok, mint a pezsgő: ha sikeresek vagyunk, megérdemeljük, ha nem, szükségünk van rá.” (Bauer [1981] 91. o.)

Bauer szerint a fejlesztési segélyek legnagyobb büne az, hogy az átpolitizáltság irányába terelik az országokat:

„...a fejlesztési segélyekkel a donor ország a fogadó ország belpolitikájának része lesz.” (Bauer [1961] 120. o.)

Rámutat még arra is, hogy a segélyezett országokba való ilyen jellegű beavatkozás helyi szinten a piacellenes hangulatot füti, mert

„...mindaz, amit a harmadik világ tanul a Nyugattól vagy a jelenlegi, esetleg a múltbéli gazdasági kapcsolatokról a Nyugat és a fejlődő világ között, a piac ellenzőinek nézőpontja."(Bauer [1978] 172. o.)

Bauer-Yamey [1986] szerint például egészségesebb annak hangsúlyozása, hogy egyetlenegy üzletember sem annak köszönheti a gazdagságát, hogy azzal a céllal adományoz pénzt embereknek, hogy közülük néhányan később megvásárolhassák a termékeit. A kereskedelem Bauernél fontos volt, de nem ilyen kontextusban. 


\section{A kereskedelem szerepe a fejlödés előmozdításában}

Ahogyan azt az előzőkben láthattuk, a második világháború utáni konszenzus az volt, hogy

„...a külkereskedelem hiábavaló a legkevésbé fejlett országok (least developed countries) gazdasági növekedésének előmozdításában, sőt többnyire káros. A központi tervezés és a nacionalista gazdaságpolitika is egyetértett abban, hogy a növekedés gazdasági szuverenitással jár együtt, és mindkettő elutasította a szabadkereskedelem kölcsönösen előnyös lehetőségeit. Sokan ezért egyszerűen úgy vélték, hogy a legkevésbé fejlett országok növekedése azon tőkenagyságtól függ, amelyet az infrastruktúra, a feldolgozóipar fejlödésére és a gazdaságok modernizálására fordítanak." (Bauer [1984] 1. o.)

Az akkori konszenzus a külső tényezők megértésén alapult és azon, hogy általánosan felelősséget kell vállalnunk a legkevésbé fejlett országokban élők szegénységéért, mert a gazdagok jövedelme mások kizsákmányolásából adódik, és nem az elvégzett munka eredményét tükrözi. Ez az elképzelés, amely ugyan egybecseng Marxéval, de jelentős mértékben felerősödött azon ideológiai megközelítésben, amelyben a tulajdonlásból származó jövedelem kizsákmányolást jelentett, és a szolgáltatási ágazatot terméketlennek tartotta (Bauer [1974] 299. o.).

A mainstream fejlesztési elméletek egyszerüen figyelmen kívül hagyták a kereskedelem liberalizációjából adódó dinamikus hasznokat. Ez leginkább csak azért volt lehetséges, mert a fejlődés kereskedelem általi serkentése a 18. és 19. századi kereskedelmi elméletekre emlékeztetett, sokak szemében pedig az a fajta kereskedelem, amely testvériséget és kultúrát ígért, kizárólag a gazdasági kizsákmányolás álszent üzenete volt, amelyet legföképpen a gazdagok terjesztettek. Bauer ezt a gondolatmenetet sohasem tudta elfogadni, és rámutatott, hogy a fejlődés-gazdaságtan akkori ortodoxiája erősen épített a marxista-leninista nézetekre.

Bauer szerint ez a hatás négy csatornán keresztül szürődött be az elméletbe. 1. A fejlődő világ nemcsak kétségbeejtően szegény, hanem képtelen a fejlődésre, sőt még fokozatosan el is szegényedik. Ez pedig a proletariátus folyamatosan növekvő szenvedésével állítható párhuzamba. 2. A fejlődő országok gazdag országok általi kizsákmányolása a legfőbb okozója a szegénységnek. 3. A politikai függetlenség értelmetlen gazdasági függetlenség nélkül, amely elképzelés voltaképpen annak a kiterjesztése, hogy a politikai szabadság és a képviseleti kormány értelmetlen kapitalista rendszerekben. 4. Az átfogó fejlesztési tervezés nélkülözhetetlen a gazdasági növekedéshez, különösképpen azon iparosításhoz, amely az anyagi elörehaladáshoz szükséges (Bauer [1976] 165. o.). Bauer tapasztalatai alapján pontosan látta:

„A kereskedőkkel való kapcsolattartás és önmagában a kereskedelem az egyik legfontosabb eszköze az új eszmék, a viselkedési módok és a termelési metódusok terjedésének. A külső kereskedelmi kapcsolatok elsőként a változás lehetőségét vetik fel, amelynek eleme a gazdasági növekedés is." (Bauer [2000] 8. o.) 
„...egyrészről a gyarmatosítás maradványainak minden formában való felszámolása, másrészről pedig a természeti erőforrások felett gyakorolt szuverén jogok gyakorlása jelenti a szükséges feltételt a gazdasági növekedéshez.” (Bauer [1974] 303. o.)

„Ennek tükrében pedig nem meglepő, hogy a harmadik világ országaiban leginkább a fejlett régiók azok, amelyeknek a legtöbb nyugati kereskedelmi kapcsolatuk volt, és a legfejletlenebbek és a legszegényebbek pedig azok, amelyeknek kevés." (Bauer [2000] 5. o.)

Olvasatában a nyugati termékek elérhetősége a legkevésbé fejlett országokban élőkre ösztönzően hat, ugyanis a többletmunka, a megtakarítás és a befektetések segítségével megvásárolhatják az újonnan elérhető luxustermékeket. Bauer különösen hevesen szállt szembe azzal a fejtegetéssel, amely szerint „a fejlett országokkal való kapcsolatok károsak a fejlődő országok számára” (Bauer [1957] 65. o.). Ennek a nézőpontnak szerinte rendkívül erős marxista háttere volt, és úgy vélte, hogy azon országok, amelyek elzárkóznak a nemzetközi munkamegosztás előnyeitől, súlyos árat kénytelenek fizetni.

„A kereskedelmi kapcsolatok és a tartalékkészletek hiánya balszerencsét hoz, mert a rossz időjárás katasztrófát idézhet elő, a megszorítások pedig éhezést. [...] lehet valami abban a gúnyos megjegyzésben, hogy központilag irányított gazdaságokban még az időjárás is rossz." (Bauer [2000] 7-8. o.)

Bauer jól látta, hogy a belső és a külső piacok verseny előtti megnyitásával a kormányok megteremthetik az anyagi gyarapodás megfelelő bázisát. A probléma viszont már akkor is az volt, hogy a harmadik világ országainak „érdekeit” érvényesítők leginkább a status quo megőrzésében voltak érdekeltek. A kormányzati monopóliumokkal való leszámolás és a kereskedelem liberalizációja természetesen segítene a szegényeknek, de károsan érintené a politikailag erős csoportokat, így a változás nehezen kivitelezhető. A protekcionista intézkedések visszavetik a gazdasági növekedést, így a harmadik világbeli országok a szegények megsegítésének érdekében külső segélyekért folyamodnak. Bauer erre a megközelítésre mint veszélyes tévútra és zsákutcára tekintett, mert ahogyan azt kiemelte, a szegényeket duplán sújtják az állami monopóliumok és a vámok versenyellenes, valamint a kormányközi transzferek korrupciós hatásai.

Ma már jól ismert tény, hogy a kereskedelembe intenzíven bekapcsolódó fejlődő országok valóban lendületes gazdasági növekedést értek el. Ezzel ellentétben a legszegényebb országok pontosan azok maradtak, amelyeket a kereskedelmi áramlások elkerültek, s annak ellenére nem sikerült tartós felemelkedést elérniük, hogy a nemzetközi segélyezéssel kétoldalú vagy multilaterális segélyakciókon keresztül komoly fejlesztési forrásokat kaptak.

\section{Bauer mint az egyéni szabadság és választás leglelkesebb támogatója}

Bauer értelmezésében Myrdal legfontosabb tézise az volt, hogy az egyén személyes magatartását és társadalmi hozzáállását úgy kell átalakítani, hogy az a nagyobb egy före jutó jövedelem érdekeit szolgálja (Bauer [1976] 188. o.). Ennél talán semmit sem tagadott jobban Bauer, és kifejtette: 
„A népesség feletti állami ellenőrzés kiterjesztésével a központi tervezés csak megerősíti az egyén bürokráciának való alávetettségét. Ez a fajta változás torzítja az önállóságot, a személyes jövőképet, az egyén kíváncsiságát és a kísérletező szellemét is.” (Bauer [1976] 84. o.)

Dorn [2002] szerint Bauer a fejlődés lényegét (essence of development) éppen az egyén választási szabadságának kiterjesztésében (expansion of individual choices) látta. Erröl Bauer 1957-ben így írt:

„A választási lehetőségek kiterjesztését, tehát az egyén számára elérhető hatékony alternatívák számának növekedését a gazdasági növekedés elsődleges célkitűzésének és kritériumának látom, és bármilyen intézkedést alapvetően az alapján értékelek, hogy annak milyen hatása van az egyének szempontjából rendelkezésre álló választási lehetőségek számára. [...] E célkitüzés elfogadása azt jelenti, hogy nemcsak jelentőséget, hanem értelmet is tulajdonítok a választás és az értékelés egyéni cselekményének, amibe beletartozik az egyénnek a jelenre és jövőre vonatkozó időpreferenciája is. [...] Meggyőződésemet nagyban befolyásolja azon politikai döntések kapcsán érzett ellenszenvem, amelyek nagy valószínűség szerint az egyik egyén hatalmát növelik egy másik egyén felett. Ez voltaképpen az az eset, amikor egyes csoportok vagy egyének ellenőrzése növekszik az azonos állampolgárokkal szemben.” (Bauer [1957] 113. o.)

„...néhány ember azon joga, hogy rákényszerítse másokra a fejlődést, legkevésbé sem magától értetődő, különösen akkor, amikor a választási lehetőségek szélesedését és az alternatívákhoz való hozzáférést tekintjük a gazdasági fejlődés legfontosabb előnyének.” (Uo. 122. o.)

Bauer [1957] szerint a fejlődés valódi lényege az a spontán szabadpiaci folyamat, amely megnöveli az egyén választási szabadságát. A kényszerítő erejü, állam által irányított fejlesztési politika, amely megtagadja az egyéntől a lehetőségek közötti választás szabadságát, csak álfejlődés (pseudo development).

„A modern piacgazdaságokban a gazdagok és különösen a rendkívül gazdagok általában a gazdagságukat olyan tevékenységeknek köszönhetik, amelyek gyarapították a teljes népesség, ezzel természetesen a szegények választási lehetőségeit is.” (Bauer [1984] 25. o.)

Bauer mélyen tisztelte a szegény emberek méltóságát, racionalitását és képességeit, s képesnek találta őket arra, hogy a központi tervezés elfogadása helyett racionális és növekedést elősegítő döntéseket hozzanak. Bauer azzal is érvelt, hogy ha azt gondoljuk, hogy a szegényebb társadalmi rétegek nem képesek a megtakarításra és a jövőbe való befektetésre, akkor egyszerüen figyelmen kívül hagyjuk a történelem tanulságait. A malajziai kisbirtokosok és a nyugat-afrikai kiskereskedők például előrelátók voltak, és megvolt az ösztönzőjük is ahhoz, hogy lemondjanak az aktuális fogyasztásuk egy részéről. Tették ezt annak érdekében, hogy olyan növényeket ültessenek, amelyeket éveken keresztül kell gondozni ahhoz, hogy a termésük a piacon értékesíthető legyen (Bauer [1948], [1954]). Kényszerítésre tehát legkevésbé sem volt szükség:

„[A]mi történt, az nagy részben több millió embernek a sokasodó külső kapcsolatokból és a piaci lehetőségekből adódó önkéntes reakciója volt. Ez a fejlődés pedig azért volt lehetséges, mert a közpénzek tekintetében és a külső források elérhetőségében korlátozott volt az állam szerepe." (Bauer [1991] 191. o.) 
Szerinte a kiskereskedőkből és boltosokból álló társadalmi csoport nagyban segíti a kereskedelmi intézmények és a megfelelő gyakorlat létrehozását, ami hozzájárul az emberi tőke növekedéséhez (Bauer [2000] 4. o.). Kiemelte ugyanis, hogy a kisebb kereskedők például piaci szolgáltatásokat és hitelt nyújtanak ügyfeleik számára, és ez a hitelnyújtás az utolsó láncszem a világ pénzügyi piacain jelen lévő nagyobb pénzügyi intézmények láncolatában. A vidéki farmerek számára ez közvetett hozzáférést jelent a világ pénzügyi piacaihoz (uo. 10. o.). Azon szakértők pedig, akik görcsösen ragaszkodtak ahhoz, hogy csak a nagyszabású tőkebefektetésekkel lehet mérsékelni a legkevésbé fejlett országok szegénységét, egyszerüen kihagyták az érvelésükből ezen informális kapcsolatokat és a kisebb tőkepiaci projekteket, vagyis számukra nem volt kiemelten fontos az egyének választási szabadsága.

Bauer számára igazán meghatározó az önkéntes csere (voluntary exchange). A gazdasági növekedést érintő nézőpontja alapvetően smithi: úgy véli, hogy a piac kiterjedtsége határozza meg a munkamegosztás fokát. Szerinte minél nagyobb a munkamegosztás, annál jobb, minél kiterjedtebb a piac, annál hatékonyabb. Nagyon találóan az utolsó könyvének magyarra fordítva $A$ megélhetéstöl a cseréig címet adta (Bauer [2009]), mert értelmezése szerint a fejlődésnek két pólusa van. S mivel az elszakadás az önellátásra való termeléstől kereskedelmi tevékenységet feltételez, ez lépésről lépésre nagyobb tudáshoz, jobb koordinációhoz, végezetül pedig növekvő termeléshez vezet. Ezt a folyamatot, átalakulást pedig a kereskedelem minden szinten segíti. Bauer valóban értékelte, hogy a társadalom szegényebb rétegeiben jó kereskedők vannak. Azt gondolta továbbá, hogy meg kell értenünk a helyi körülmények sajátosságait, mielőtt mindent átfogó közpolitikai intézkedéseket hozunk. Szerinte a kultúrának nagy szerepe van a fejlődésben, de nem gondolta, hogy a szélesebb értelemben vett Délen irracionális gazdasági szereplők laknak, akiknek feltétlenül szükségük lenne a felvilágosult gondolkodók tanácsaira. Akár a fejlődésről, a migrációról, a túlnépesedésről írt is, a paternalizmust mindig elvetette.

Bauer a fejlődési kérdések tárgyalásakor nemcsak a nemzeti jövedelem növekedésére, hanem a gazdasági szabadság bővülésére is súlyt helyezett. A kettő természetesen összekapcsolódik, de számottevő különbségek is jelentkeznek. Egy központosított gazdaságban például magas lehet a gazdasági növekedés foka, de nincs meg az egyén választási szabadsága, ugyanis az elnyomó kormányok szükre szabják a gazdaságilag hatékony lehetőségek számát (Bauer [1984] 126. o.).

\section{Miért nem (volt) népszerü mindaz, amit Bauer képviselt?}

Bauer munkássága során többször rámutatott a nyilvánvaló valóság széles körü figyelmen kívül hagyására, és számos alkalommal hangsúlyozta, hogy a fejlődésgazdaságtan területén egyszerre volt jelen az elmélet látványos fejlődése és riasztó visszafejlődése. Szerinte az előrelépés a nemzetközi kereskedelem elméletének és a tulajdonjogok gazdaságtanának területén történt, emellett pedig még fontos volt a tranzakciós költségek jelentőségének felismerése is. A visszalépés pedig az ő olvasatában az alapvető gazdasági rendezőelvek figyelmen kívül hagyása, a fogalmi 
zavar, a hatásvadász módszertani megközelítés és a közvetlen megfigyelés hiánya volt (Bauer [2000]).

Különösen nyugtalanítónak tartott néhány megközelítést a közgazdaságtan területén. Az általa hangsúlyozott neuralgikus pontok közül néhány még ma is létezik, és ezek magyarázatot adhatnak arra, hogy miért hagyják Bauert figyelmen kívül azok, akik akár ugyanazon következtetésekre jutnak, és hasonló gazdaságpolitikai intézkedéseket szorgalmaznak.

1. Bauer már a kezdetektől szembehelyezkedett azokkal a nézetekkel, amelyek a fejlődő országokban az extenzív állami beavatkozást támogatták. Nézetei szöges ellentétben álltak például Myrdal következő megállapításaival:

„A fejlődést előmozdító tervezés sikere minden társadalmi réteg esetében azt követeli meg az egyéntől, hogy sokkal nagyobb áldozatokat hozzon, mint amilyeneket jelenleg a délázsiai országokban hoznak. Ez ráadásul a kötelezettségek szigorú végrehajtását is megköveteli, amelyben a kényszer is stratégiai szerepet játszik." (Myrdal [1968] 67. o.)

„Csak egyetlen út vezet a gazdasági fejlődéshez, és ez a nemzeti jövedelem erőteljes növekedése, amihez a fogyasztástól csoportosítanak át a befektetésekhez, ez pedig a legnagyobb megszorítások gazdaságpolitikáját jelenti.” (Myrdal [1956])

2. Bauer rámutatott arra is, hogy a fejlődés tanulmányozásakor a statisztikai tények, a matematika és a túlzott számszerüsítés alkalmazása korlátokba ütközik. Egyrészről azt hangsúlyozta, hogy sokan túlságosan nagy súlyt fektetnek az olyan látszólag mérhetö tényezőkre, mint a töke, másrészröl pedig nem tulajdonítanak jelentőséget a fejlödés szempontjából fontos történelmi összefüggéseknek és az alapfeltételeknek (Bauer [2000] 19. o.). Számára alapvető volt a közvetlen megfigyelés és az elsődleges forrásokra való támaszkodás. Ez a szemlélet Bauert kivételesen interdiszciplinárissá tette, ugyanis munkáiban történészek, antropológusok, könyvelők és még utazók írásaira is támaszkodott. Így a kritikai szemlélete és a megközelítései még idegenek voltak az akkor uralkodó közgazdasági gondolkodástól.

„Mi lett a közvetlen megfigyelések hagyományos módszereivel, a reflexiókkal, a kapcsolatok nyomon követésével, a kezdeti következtetések levonásával és ezek visszautalásaival a megfigyelésekre, továbbá a tudományterület már rég leírt ajánlásaival vagy a társdiszciplínák eredményeivel?" (Bauer [2000] 20. o.)

Ahogyan arra Vásquez [2007] rámutat, Bauer fejlődési modellekkel szemben megfogalmazott kritikája a formális analízist túlharsogó megközelítéssel kapcsolatos bizalmatlanságát fejezte ki. A modellek az aggregált és a kvantitatív megközelítést hangsúlyozták a fejlődés-gazdaságtan területén, viszont Bauer arra figyelmeztetett bennünket, hogy a növekedési modellek „nem segítik a megértést, sőt inkább félrevezetők” (Bauer [1984] 34. o.). Szerinte egyszerüen elfeledkeznek arról a tényröl, hogy a paramétereket sokszor jelentéktelen változók befolyásolják. Azzal érvelt, hogy az egyéni attitüdök és a politikai helyzet - amelyet a növekedési modellek gyakran egyszerủen kihagynak - sokkal fontosabbak a fejlődés megértésében, mint a tőkeállomány vagy éppen ennek vámokkal való növelése. 
Bauer egészen karcosan fogalmazott, amikor a növekedési modelleket paródiákhoz hasonlította (Bauer [1972] 285. o.). Hangsúlyozta ugyanis, hogy azok kizárólag arra szolgálnak, hogy igazolják az elhibázott gazdaságpolitikai intézkedéseket és a közvetlen megfigyelések nélkülözését.

„Ennek eredményeként a fejlődés-gazdaságtannal foglalkozók gyakran olyan társadalmakat, rendszereket és helyzeteket értékelnek és tanulmányoznak, amelyeket nem ismernek igazából. A szó legszorosabb értelmében nem is feltétlenül tudják, hogy miről beszélnek." (Bauer [1972] 289. o.)

Még arra is felhívta a figyelmünket, hogy amíg a természettudományok területén gyümölcsöző lehet a változók logikai megfelelés, egyszerűség vagy az elemzés eleganciája szerinti megválasztása, addig ez a társadalomtudományokban nem így van. Ezen a területen a probléma összetettségének felismerése nélkülözhetetlen a helyes eredmények eléréséhez (Bauer [1972] 284. o.).

Bauer szerint a fejlődés-gazdaságtani kérdésekkel foglalkozók azért hagyták figyelmen kívül az egyébként fontos tényeket és alapelveket, mert egyszerüen nem vették figyelembe, hogy valójában miként élnek az emberek a fejlődő országokban, így mindig is szűk látókörüek (armchair expert) voltak. Az írásaiban nemcsak vitába szállt az általa hamis konszenzusnak (spurious consensus) nevezett eredményekkel, hanem gyakran meg is mutatta, hogy miért van nagyobb különbség a fejlesztési ortodoxia és a valóság között. Ez a fajta látásmód és retorika nem tette Bauert népszerűvé a kortársai és azon intézmények körében, amelyek számos fejlődés-gazdaságtani szakértőt alkalmaztak.

3. Deepak Lal rámutatott arra, hogy a mainstream közgazdaságtan és Bauer között feltárható disszonancia leginkább annak a következménye, hogy Bauer a közgazdaságtant ismeretelméletileg túlzottan pozitivista szemléletben tüntette fel ( $\mathrm{Lal}$ [1987] 46. o.).

Bauer arra figyelmeztetett, hogy nem szabad úgy megközelíteni a közgazdaságtant, mintha az müszaki tudomány lenne. Szerinte az adatok természetesen fontosak, de ugyanúgy fontosak a közvetlenül megfigyelhetö kapcsolatok. Ezek között pedig vannak olyanok, amelyeket nem egyszerü számszerüsíteni; ilyenek például az attitűdök és az idődimenzió is. Bauer ezt a kérdéskört így szemléltette:

„Az a szerencsétlen szembeállítás, amelyet gyakran a mezőgazdaság és az ipari termelés között tesznek, leginkább az előbbi kárára, jó példája azon, idődimenziótól megszabadított fejlődés-gazdaságtani megközelítésnek, amely teljességgel alkalmatlan a társadalmak történeti fejlődésének megértésében." (Bauer [1972] 144-145. o.)

Bauer azzal is gyakran érvelt, hogy azok a gazdasági korlátozó intézkedések (restrictive measures), amelyek alkalmazása népszerű volt az afrikai kontinens nagy részén és a fejlődő világban, nélkülözték a gazdaságtörténet alapos ismeretét:

„...ezen gazdaságok nem járták be a fejlett országok viszonylagosan korlátlan gazdasági tevékenységének hosszú útját, így a hatékony gazdasági korlátozások túlzottan korai bevezetése érzékelhetően visszavetheti a gazdasági növekedési ütemüket.” (Bauer [1972] 45. o.) 
Ugyancsak Deepak Lal hívja fel a figyelmünket arra a fontos magyarázatra, hogy a Bauer-féle megállapításoknak miért nem tulajdonítottak nagy jelentőséget. Szerinte a közgazdászok fiatalabb generációja számára egyszerủen ismeretlen a személye. Arra emlékeztet bennünket, hogy a negatív értékelések miatt Bauer munkáit már a saját kortársai is nagyban leértékelték, és nem is hivatkozták ( Lal [1987] 43. o.).

\section{Volt-e Bauer munkásságának tényleges hatása és utóélete?}

Bauer a Cato Institute 25. évfordulójának ünnepségén, 2002. május 9-én - halála után egy héttel - posztumusz kapta meg a Milton Friedman Prize for Advancing Liberty díját. Az eseményen Milton Friedman a következő szavakkal fejezte ki a Bauer iránti csodálatát:

„Kevés olyan dolog van, amely fontosabb annál, mint hogy megbecsüljük azokat az embereket, akik a szabadságért szálltak síkra az egész világon. Bauer megérdemli ezt a díjat. Ötvenéves barátságunk alatt mindig következetesen és kitartóan olyan gondolatokat képviselt, amelyek ugyan népszerütlenek, de feltétlenül helyénvalók voltak." (Dorn [2002] 355. o.)

Jelen tanulmányban már láthattuk, hogy Bauer nézőpontját ténylegesen kevesen osztották, és erre vonatkozóan Amartya Sen meg is jegyezte:

„Peter Bauer kiváló közgazdászként a saját osztályának a tagja volt. Az írásainak eredetisége, ereje, kiterjedt csapásiránya egészen megdöbbentőnek bizonyult, és egyértelmüen ö az egyik legjelentősebb alakja a politikai gazdaságtannak.” (Sen [2000] 9. o.)

Többnyire az 1950-es és 1960-as években azonban - ahogyan azt Desai [1982] is hangsúlyozza - Bauer kritikailag kevésbé alátámasztott írásaival többekben leginkább haragot keltett. Nélkülözték, elutasították, és a felvetéseit mellőzték. Bauer gondolatainak fogadtatását jól tükrözi Nicholas Stern írása, aki Bauer 1972-ben megjelent, Dissent of Development címü könyvét egészen gorombán támadta, és azt írta, hogy a munka nem egy értékes hozzájárulás a fejlődés tanulmányozásához (Stern [1974] 209. o.). ${ }^{6}$

Bauer szakmai fogadtatását jól jellemzi még az is, amikor Walt Whitman Rostow Bauert „neoklasszikus bögölyként” írta le, akinek más, fejlődés-gazdaságtannal foglalkozó szakemberek megértéséhez nyújtott hasznosságát az ördög ügyvédjéhez hasonlította (Rostow [1990] 336. o.). A korábbiakban már láthattuk, hogy annak ellenére, hogy Bauer valóban következetesen képviselte álláspontját, változó megítélést kapott. Elöször szélsőségesen heterodoxnak bélyegezték, majd néhány évvel később, a Thatcher-/ Reagan-korszakban önkéntelenül is a mainstream része lett.

\footnotetext{
${ }^{6}$ Stern segélyezéshez való hozzáállása egyébként végtelenül egyszerű volt: a gazdag országokban élő emberek sokkal gazdagabbak, mint a szegény országokban élők, és ezért a segélyezés erkölcsi kötelesség.
} 
Bauer helyet kapott abban a World Bank által 1984-ben publikált tanulmánysorozatban, amelyben a második világháború utáni fejlődés-gazdaságtannal foglalkozó tíz legnagyobb hatású közgazdász munkái szerepeltek (Meier-Seers [1984]). ${ }^{7}$ Ebben olyan tudósok mellett említik, mint Arthur Lewis, Paul Rosenstein-Rodan vagy Gunnar Myrdal. Ez a rövid felsorolás ismét bizonyítja, hogy munkásságát valóban rendkívül erős ellenszélben fejtette ki. Dorn [2002] és Scheifer [2009] szerint azonban egészen meglepő, hogy a nézeteit napjainkban még mindig nem ismerik szélesebb körben. Sokan Bauert olyan úttörőnek és tudósnak tartják, akinek hatalmas elörelátó képessége volt. A nyitott kelet-ázsiai gazdaságok sikere és a központi tervezés összeomlása voltaképpen az általános nézeteit igazolta. A szakirodalom tanulmányozásakor, ahogyan azt a következőben láthatjuk majd, elvétve találkozhatunk a nevével. Elörebocsátható, hogy Bauert még akkor sem feltétlenül említik, ha ő mutatott rá elsőként az adott összefüggésre.

Vásquez [2007] az American Economic Review tanulmánykeresőjét futtatta, és az 1911-2004-es időszakban mindösszesen hét olyan tanulmányt talált, amelyben hivatkoztak Bauerre, és három könyvismertetést, amelyben idézték. A World Bank saját folyóirataiban, a World Bank Economic Review-ban és a World Bank Research Observerben nevét mindösszesen hatszor idézik, így a szerző azt a sommás következtetést vonja le, hogy a fejlődési és növekedési kérdésekkel foglalkozó közgazdászok közül alig érdeklődnek Bauer munkássága iránt. Kivételek azonban mindig vannak. Dambisa Moyo mindamellett, hogy Dead Aid címü művét Peter Bauernek szánja, felhívja a figyelmünket arra, hogy a fejlesztési segélyek nemcsak aláássák a gazdasági növekedést, hanem politikai bizonytalanságot okoznak, és egyes esetekben polgárháborúhoz is vezetnek (Moyo [2009]). Hasonló kérdéskört feszeget Graham Hancock 2009-ben újra kiadott, de 1989-ben írt, Lords of Poverty címü könyve. A szerző Bauer szavait igazolja, és könyvében öt esetben is említi.

William Easterly egy 2005-ös, Ian Vásquezhez írt elektronikus levélben ezt mondja Bauerről:

„Csodálatos annak a felismerése, hogy a hozzám hasonló szerzőtársak és a saját kutatásaimnak és nézeteimnek jelentős részét Bauer már jócskán megelőzte, anélkül hogy ezt észrevettük volna. Ennek kevésbé látható példája Bauer szkepticizmusa azon befektetéseket és a tőkefelhalmozást illetően, amelyek a gazdasági növekedésben meghatározó tényezőként jelentkeznek. Éppen ezt a nézetet osztottuk mi is néhányan, Ross Levine-nel és Lant Pritchett-tel az utóbbi évtized számos tanulmányában." (Vásquez [2007] 208. o.)

\footnotetext{
${ }^{7}$ Emellett meg kell említeni, hogy még Bauer életében, 1997-ben a World Bank is beismerte, hogy azon elképzelés, mely szerint „a megfelelő tanácsadók és a műszaki szakértők megfelelő gazdaságpolitikai intézkedéseket hoznak, amelyeket a megfelelő kormányok végre is hajtanak a társadalom haladásának reményében, naivnak bizonyult. A kormányok grandiózus tervekbe fogtak. A magánbefektetők, nem bízván a közpolitikai intézkedésekben vagy éppen a vezetők kitartásában, elmaradoztak. Az erős uralkodók önkényesen cselekedtek, és korrupció mély gyökereket vert. A fejlődés elakadt, és a szegénység tartós maradt." (World Bank [1997] 1-2. o.) Éppen az történt tehát, amit Bauer megjósolt. A World Bank még arra is rámutatott, hogy az állam által vezérelt beavatkozások csak súlyosbították a piaci kudarcokat, és arra jogosították fel az államot, hogy korrigálja azokat. Ezen nézet intézményi feltételezése azonban, ahogyan mára már világossá vált, túlságosan leegyszerüsítőnek bizonyult (uo. 1. o.).
} 
Easterly mindezt részben azért írja, mert a 2006-ban megjelent, The White Man's Burden címü könyvében statisztikai úton mutat rá arra a tényre, hogy 1970 és 2000 között a fejlesztési segélyezés és a gazdasági növekedés közötti kapcsolat bizony fordítottan arányos. ${ }^{8}$ Annak ellenére, hogy ebben az időszakban a segélyek nagysága drasztikusan emelkedett, a gazdasági teljesítmény visszaesett, ami negatív növekedési mutatókban is testet öltött. Minél több segély érkezett az afrikai kontinensre, annál inkább lelassult a gazdaság növekedése, és annál inkább emelkedett a szegénység szintje (Easterly [2006]). A szerző egy másik müvében, a 2013-ban megjelent Tyranny of Expertsben azonban kifejti, hogy valójában nem tulajdonít nagyobb jelentőséget a munkáinak. Teszi ezt annak ellenére, hogy könyve tökéletes forgatókönyv lett volna a Bauer által felvázoltak számára. Easterly ugyanis leírja, hogy hogyan térítették el a fejlődésgazdaságtant a technokrata „társadalmi mérnökök” (social engineers). Egy másik könyvében idézi először Bauert, és megállapításaival kapcsolatban a „szarkasztikus” és az „elörelátó” szavakat használja (Easterly [2002] 34. o.). Bauer egyik müvét, az 1976-ban megjelent Dissent on Developmentet pedig olvasásra is ajánlja.

Angus Deaton, a 2015-ös év közgazdasági Nobel-díjasa A nagy szökés címü munkájában elismerte, hogy Bauernek igaza volt a fejlesztési segélyezés és a népesedés tekintetében.

„A szabadon rendelkezésre álló nemzetközi magántőkemozgások mérete mellett minden eltörpül, amire Bauer egyáltalán gondolhatott, ezért ha érvelése helytálló volt 1971-ben, akkor ma még inkább az." (Deaton [2017] 325. o.)

Sokan a fejlödés-gazdaságtan alapmüvének tekintik Michael P. Todaro és Stephen C. Smith Economic Development címü müvét, amelynek 2015. évi kiadásában háromszor olvashatjuk Bauer nevét: egyszer egy felsorolásban, két esetben pedig lábjegyzeti hivatkozásban (Todaro-Smith [2015]). Ugyancsak sokak által használt tankönyv a Process of Economic Development címü mü, amelyben Bauer neve meglehetösen sokszor szerepel, és a szerzők majdnem egy fél fejezetet szánnak munkássága egy szeletének (Cypher-Dietz [2009]).

Meg kell még említenünk Debraj Ray Development Economics címü könyvét is, amelyben egyetlen utalás sem történik Bauerre (Ray [2014]).

Daron Acemoglu és James Robinson Miért buknak el nemzetek? címü könyvében azonban egyszer sem szerepel Bauer neve (Acemoglu-Robinson [2012]). Nem említi Acemoglu Jonhsonnal írt, számtalan hivatkozást kapott tanulmánya sem (AcemogluJohnson [2005]). Mindez annak tükrében érdekes, hogy a két munka nagyrészt alátámasztja Bauer tulajdonjogokkal kapcsolatos állításait.

Tobias Hagmann és Filip Reyntjens 2016-ban megjelent könyvének címe Aid and Authoritarianism in Africa. A cím alapján számíthatnánk arra, hogy a szerzők megemlítik Bauer nevét, munkájukban azonban egyetlen említés sem

\footnotetext{
${ }^{8}$ Ilyen vizsgálatot Vásquez [1998] is végzett: 73 országot vizsgált az 1971-es és 1995-ös időszakban, és nem talált pozitív összefüggést a fejlesztési segélyezés és a gazdasági növekedés között. Söt enyhén negatív kapcsolatot tárt fel. Arra is rámutatott, hogy azon 20 ország közül, ahol 1985-1990 között a gazdasági szabadság besorolása nem változott vagy csökkent, 19 esetében jelentős GDP-arányos fejlesztési segélyezés történt.
} 
történik (Hagmann-Reyntjens [2016]). Robert Calderisi The Trouble with Africa címü könyvében Bauer [1981]-et egyszer említi (Calderisi [2005] 159. o.). Kenneth Kalu Foreign Aid and the Future of Africa címü könyve egyszer sem hivatkozik Bauer munkáira (Kalu [2018]).

Peter T. Leeson arra vállalkozik, hogy kimondottan Bauer két feltételezését igazolja. Egyrészt arra volt kíváncsi, hogy valóban visszaveti-e a gazdasági növekedést a fejlesztési segélyezés, másrészt pedig arra kereste a választ, hogy ténylegesen milyen szerepe van a tulajdonjognak a gazdasági növekedésben. Több szerző empirikus elemzését szintetizálva arra a következtetésre jut, hogy Bauer provokatív feltételezései igazak voltak, és előrevetítették a tudományterület későbbi eredményeit. Felhívja azonban a figyelmünket, hogy

„Bauer éleslátásának növekvő felismerése valószínűleg nem lesz elengedő ahhoz, hogy szűkítse a fejlesztési segélyezés és a kormányok által irányított fejlesztések mozgásterét." (Leeson [2008] 60. o.)

Magyarországon talán még kevesebben ismerik Bauer nevét, és nagyjából maroknyian hivatkozzák és említik. Csaba László mester- és doktori képzésben tartott kurzusain rendre felhívja a figyelmet munkásságára, írásaiban gyakran hivatkozik is rá (Csaba [2006], [2014] 41. o., [2018] 7. o.). Bod Péter Ákos több előadást is tartott Bauer elméleteiről, ${ }^{9}$ és szellemi örökségéről tanulmányt is közölt (Bod [2017]). A Pásztor [2018a] tanulmány - Bod Péter Ákoshoz hasonlóan - rövid számvetést adott munkásságáról. Néhány esetben még elöfordul, hogy tanulmányokban (Ricz [2005]) és doktori értekezésekben (Ricz [2008], Szent-Iványi [2009]) bukkan fel Bauer neve, de elméletei és meglátásai korántsem a gondolatiság fő csapásirányát jelentik.

Ettől eltekintve a főiskolai, egyetemi és PhD-hallgatók sokasága sohasem hall Bauerről, hiszen a hazai képzőhelyeken a fejlődés-gazdaságtani oktatás gerincét a már korábban is említett, Economic Development címü könyv jelenti (Todaro-Smith [2015]), amelyben Bauer korántsem „föszereplö". Magyar nyelvre egyetlen könyvét sem fordították le, ami mögött számos ok húzódhat meg. Egyrészt még a nyugati világban is szélsőségesen piacpártinak tartották, és a hazai közgazdasági gondolkodásnak nem feltétlenül volt mindenkor szerves része a fejlesztési segélyezés kutatása. Másrészt pedig a rendszerváltozás után sokak szemében az általa leírtak már annak ellenére idejétmúlttá váltak, hogy Bauer szinte nyomban felismerte, hogy a korábbi kommunista országokban az átmenet segítéséhez piacbarát intézményhálózatot kell létrehozni ahelyett, hogy az egyéneket kormányzati segélyektől tennénk függővé. Hangsúlyozta még azt is, hogy a nyugati kormányoknak meg kell mutatniuk a liberális piacgazdasághoz való ragaszkodásukat, meg kell nyitniuk a piacaikat a keleti

\footnotetext{
${ }^{9}$ Ezek közül kiemelkedik egyrészt az az angol nyelvü konferencia, melynek címe: P. T. Bauer: A Hungarian in Cambridge volt. Az eseményt a Danube Institute a Magyar Nemzeti Bankkal, a milánói Bruno Leoni Intézettel, a Magyarország Barátai Alapítvánnyal és az Egyesült Királyság budapesti nagykövetségével karöltve rendezte a Magyar Nemzeti Bankban 2018. március 17-én (Pásztor [2018b]). Másrészt pedig a Pázmány Péter Katolikus Egyetem Jog- és Államtudományi Karának 20. századi híres magyar közgazdászokról szóló konferenciáját érdemes kiemelni, amelyet 2018. november 14-én rendeztek meg Budapesten.
} 
országok előtt, és liberalizálniuk kell a kereskedelmi kapcsolatokat is (Bauer [1998]). Ennek tükrében kevésbé érthetö, hogy a posztkommunista érában Bauer munkái miért esnek még mindig kívül a közgazdasági szakma érdeklődésén.

\section{Összefoglalás és következtetések}

A tanulmányból láthattuk, hogy Bauer munkássága a központi tervezés bírálatában, a piacellenes retorika ellenzésében, a szegénység ördögi körének megkérdőjelezésében, a fejlesztési segélyezés hibáinak bemutatásában, a kereskedelem fejlődést ösztönző szerepének kiemelésében és az egyéni szabadság kiterjesztésének jelentőségében volt meghatározó. Emellett azonban a legfontosabb öröksége talán az, hogy kitartásunk és gondolati tisztaságunk révén jobban megérthetjük azokat az erőket, amelyek formálják a gazdaság fejlődését. Döntő szerepük van a tulajdonjog intézményeinek, az egyének választási szabadságának, a szabadkereskedelemnek és az egészséges keretek között maradó és nem a fejlesztési segélyezésben gondolkodó kormányzatnak.

Munkáiban harcba szállt az uralkodó elméletekkel, és a fejlődő országokban szerzett tapasztalataira hivatkozva érvelt amellett, hogy a széles körben elfogadott tudományos megközelítéseknek igenis lehet alternatívája. Elméletei a korszak meghatározó nézeteit támadták, sokszor komolyabb érdekekkel is szembehelyezkedett, szélsőséges piacpártinak tartották, aki később különösen jó elméleti alapot adott Ronald Reagan és Margaret Thatcher neoliberális gazdaságpolitikájához. A 2008-as válság után megváltozott közgazdasági gondolkodásban ismét más megvilágításba helyeződik az általa hangsúlyozott piaci liberalizmus. A föáramú irányzatok változtak, Bauer azonban mindig következetes maradt, és síkra szállt a pályafutása elején a fejlődő országokban szerzett alapelveiért.

Mindezek mellett nem szabad elfeledkeznünk arról, hogy a Bauer által is szorgalmazott jóléti közgazdaságtan és az egyének választási szabadságának tanulmányozása évekkel később, 1998-ban Amartya Sen számára közgazdasági Nobel-díjat hozott, és nem túlzás azt sem kijelenteni, hogy Sen munkásságának egyik előfutára Bauer volt. Bauer fejlődésről alkotott eltérő nézeteivel, tapasztalati alapokon nyugvó érveléseivel szinte egyedül kérdőjelezte meg az állam által irányított fejlesztési modellt. Amint a fejlődés-gazdaságtan egyre nagyobb jelentőséget tulajdonít a növekedés komplex vizsgálatának, gondolatai ismét bekerülhetnek a szakirodalom föáramába - nemcsak külföldön, de Magyarországon is.

\section{Hivatkozások}

Acemoglu, D.-Johnson, S. [2005]: Unbundling Institutions. Journal of Political Economy, Vol. 113. No. 5. 949-995. o. https://doi.org/10.3386/w9934.

Acemoglu, D.-Robinson, J. A. [2012]: Miért buknak el nemzetek? A hatalom, a jólét és a szegénység eredete. HVG Kiadó, Budapest.

BARAN, P. A. [1957]: The Political Economy of Growth. Monthly Review Press, New York, 307 o. 
Bauer, P. T. [1948]: The Rubber Industry. A Study in Competition and Monopoly. Harvard University Press, Cambridge, MA.

Bauer, P. T. [1954]: West African Trade: A Study of Competition, Oligopoly and Monopoly in a Changing Economy. Cambridge University Press, Cambridge, 476 o. https://doi. org/10.1017/S1373971900061072.

BAuer, P. T. [1957]: Economic Analysis and Policy in Underdeveloped Countries. Cambridge University Press, London.

Bauer, P. T. [1961]: Indian Economic Policy and Development. Frederick A. Praeger, New York, 156 o.

Bauer, P. T. [1965]: The Vicious Circle of Poverty: Reality of Myth? Weltwirtschaftliches Archiv, Vol. 95. Szeptember, 4-20. o. https://www.panarchy.org/bauer/viciouscircle.html.

Bauer, P. T. [1972]: Dissent of Development: Studies and Debates in Development Economics. Harvard University Press, Cambridge, MA, 550 o.

BAUER, P. T. [1974]: Politicization of Knowledge: development economics. First International Interlaken Seminar on Analysis and Ideology, június.

Bauer, P. T. [1976]: Dissent on Development. Harvard University Press, Cambridge, MA, 326 o.

Bauer, P. T. [1977]: Reflections on Western Technology and „Third World Development”. Minerva, Vol. 15. No. 2. 144-154. o. https://doi.org/10.1007/bf01096674.

BAuer, P. T. [1978]: Hostility to the Market in Less-Developed Countries. Megjelent: Brunner, K. (szerk.): The First World and the Third World: Essays on the New International Economic Order. University of Rochester Policy Center Publications, Rochester-New York, 169-189. o.

Bauer, P. T. [1981]: Equality, the Third World and Economic Delusion. Weidenfeld \& Nicolson, London, 293 o.

BAUER, P. T. [1984]: Reality and Rhetoric. Studies in the Economics of Development. Harvard University Press, Cambridge, MA.

Bauer, P. T. [1987]: Creating the Third World: Foreign Aid and its Offspring. Journal of Economic Growth, Vol. 2. No. 4. 3-6. o.

Bauer, P. T. [1991]: The Development Frontier. Essays in Applied Economics. Harvard University Press, Cambridge, MA.

Bauer, P. T. [1998]: Western Subsidies and Eastern Reform. Megjelent: Dorn, J. A.-Hanke, S. H.-Walters, A. A. (szerk.): The Revolution in Development Economics. Cato Institute, Washington, 239-250. o.

Bauer, P. T. [2000]: From Subsistence to Exchange and Other Essays. Princeton University Press, Princeton, 153 o.

Bauer, P. T.-Yamey, B. S. [1986]: Development Forum, Vol. 14. No. 3. United Nations, Genf. BoD PÉTER Ákos [2017]: Segély vagy kereskedelem visz előbbre? Bauer Péter szellemi öröksége. Magyar Szemle, Új folyam, 26. évf. 9-10. sz. 119-125. o.

Calderisi, R. [2005]: The Trouble with Africa. Yale University Press, New Heaven-London.

Cypher, J. M.-Dietz, J. L. [2009]: The Process of Economic Development. 3. kiadás, Routledge, Taylor and Francis Group, New York.

Csaba LÁszló [2006]: A fölemelkedő Európa. Akadémiai Kiadó, Budapest.

CsABA LÁszló [2014]: Európai közgazdaságtan. Akadémiai Kiadó, Budapest.

CsABA LÁszló [2018]: Az intézményi gazdaságtan és a föáram. Közgazdasági Szemle, 65. évf. 1. sz. 1-23. o. https://doi.org/10.18414/ksz.2018.1.1.

DeAton, A. [2017]: A nagy szökés. Egészség, gazdagság és az egyenlőtlenségek eredete. Corvina, Budapest. 
Desai, M. [1982]: Homilies of a Victorian Sage: A Review Article on Peter Bauer. Third World Quarterly, Vol. 4. No. 2. 291-297. o.

Dorn, J. A. [2002]: Economic Development and Freedom. The Legacy of Peter Bauer. Cato Journal, Vol. 22. No. 2. 355-371. o.

Easterly, W. [2002]: The Elusive Quest for Growth. The MIT Press, Cambridge, MA-London. Easterly, W. [2006]: The White Man’s Burden. The Penguin Press, New York, 331 o.

Easterly, W. [2013]: Tyranny of Experts. Economists, Dictators, and the Forgotten Rights of the Poor. Basic Books, New York, 418 o.

Elkan, W.-Ryan, T. C. I.-Mukui, J. T. [1982]: The Economics of Shoe Shining in Nairobi. African Affairs, Vol. 81. No. 23. 247-256. o.

Hagmann, T.-Reyntjens, F. [2016]: Aid and Authoritarianism in Africa: Development without Democracy (Africa Now). The Nordic Africa Institute, Zed Books, London.

Hancock, G. [2009]: Lords of Poverty. The Power, Prestige, and Corruption of the International Aid Business. Atlantic Monthly Press, Reprint Edition, New York.

Kalu, K. [2018]: Foreign Aid and the Future of Africa. Palgrave Macmillan, https://doi. org/10.1007/978-3-319-78987-3.

Krueger, A. [1997]: Trade Policy and Economic Development: How We Learn. American Economic Review, Vol. 87. No. 1. 1-22. o. https://doi.org/10.3386/w5896.

LAL, D. [1987]: Markets, Mandarins, and Mathematicians. Cato Journal, Vol. 7. No. 1. 43-70. o.

Leeson, P. T. [2008]: Escaping Poverty: Foreign Aid, Private Property, and Economic Development. The Journal of Private Enterprise, Vol. 23. No. 2. 39-64. o.

Marsai VikTor [2015]: A szomáli szövetségi kormány első két éve és az al-Sabáb elleni katonai műveletek, 2012-2014 (I.). Nemzet és Biztonság, 1. sz. 65-95. o. http://www. nemzetesbiztonsag.hu/cikkek/nb_2015_1_08_marsai.pdf.

Meier, G. M. [1984]: The Formative Period. Megjelent: Meier, G. M.-Seers, D. (szerk.): Pioneers in Development. Oxford University Press, New York, 3-22. o.

Meier, G. M.-Seers, D. (szerk.) [1984]: Pioneers in Development. Oxford University Press, New York.

Moyo, D. [2009]: Dead Aid. Why Aid Is Not Working and How There Is a Better Way for Africa. Penguin Books, New York.

Myrdal, G. [1956]: Development and Underdevelopment. A Note on the Mechanism of National and International Economic Inequality. National Bank of Egypt, Kairó.

Myrdal, G. [1968]: Asian Drama: An Inquiry into the Poverty of Nations. Pantheon, Random House, New York, 464 o.

PÁsztor Sza bolcs [2018a]: Gondolatok Sir Peter Thomas Bauer munkásságáról. Megjelent: Halm Tamás-Hurta Hilda-Koller Boglárka (szerk.): Gazdasági, politikai és társadalmi kihívások a 21. században: Ünnepi kötet a 65 éves Halmai Péter tiszteletére. Dialóg Campus Kiadó, Budapest, 67-75. o.

PÁsztor Sza Bolcs [2018b]: Akinél a gyakorlat jövő időben szólt az elmélethez. Közgazdasági Szemle, 65. évf. 4. o. 551-554. o. https://doi.org/10.18414/ksz.2018.5.551.

Ray, D. [2014]: Development Economics. Princeton University Press, Princeton, 862 o.

Ricz Judit [2005]: Paradigmaváltás a fejlődés-gazdaságtanban. Competito, Vol. 4. No. 2. 109-123. o. https://doi.org/10.21845/comp/2005/2/8.

Ricz Judit [2008]: A fejlődés új paradigmája: elmélet és gyakorlat. Debreceni Egyetem, doktori értekezés, kézirat.

Rostow, W. W. [1990]: Theorists of Economic Growth from David Hume to the Present. Oxford University Press, New York, 736 o. 
Scheifer, A. [2009]: Peter Bauer and the Failure of Foreign Aid. Cato Journal, Vol. 29. No. 3. 379-390. o.

Schultz, T. W. [1964]: Transforming Traditional Agriculture. Yale University Press, New Haven.

SEN, A. [2000]: Introduction to From Subsistence to Exchange and Other Essays. Princeton University Press, Princeton.

Stern, N. H. [1974]: Professor Bauer on Development. Journal of Development Economics, Vol. 1. No. 3. 191-211. o. https://doi.org/10.1016/0304-3878(74)90007-8.

Szent-Iványi Balázs [2009]: A nemzetközi fejlesztési segélyezés hatékonysága. Budapesti Corvinus Egyetem, doktori értekezés, kézirat.

The Cainn [1985]: Interview with Lord Bauer. Megjelent: The Caian: The Annual Record of Gonville \& Caius College, Cambridge. 1 October 1984 to 30 September 1985. Gonville \& Caius College, Cambridge, 13 May 1985.

Todaro, M. P.-Smith, S. C. [2015]: Economic Development. Pearson Education Limited. VÁsquez, S. I. [1998]: Official Assistance, Economic Freedom, and Policy Change: Is Foreign Aid Like Champage? Cato Journal, Vol. 18. No. 2. 275-286. o.

VÁsquez, S. I. [2007]: Peter Bauer: Blazing the Trail of Development. Econ Journal Watch, Vol. 4. No. 2. 197-212. o.

World BANK [1997]: World Development Report, 1997. The State in a Changing World. International Bank for Reconstruction and Development-World Bank, Oxford University Press, New York, https://doi.org/10.1596/978-0-1952-1114-6.

Yamey, B. S. [1987]: Peter Bauer: Economist and Scholar. Cato Journal, Vol. 7. No. 1. 21-27. o. 